\title{
Útvíkkun vörumerkis og vörumerkjasamband
}

\author{
Auður Hermannsdóttir, Pálína Mjöll Pálsdóttir
}

Ágrip: Pað getur verið áhættusamt að setja nýja vöru á markað. Ein leið til að draga úr áhættunni er að kynna hina nýju vöru undir pekktu vörumerkjaheiti. Pegar fyrirtæki setur á markað nýja vöru í nýjum vöruflokki undir pekktu vörumerki er talað um útvíkkun vörumerkis. Alla jafna er talið heppilegra að vörumerki sé víkkað út í tengda vöruflokka eða vöruflokka sem á einn eða annan hátt eru eðlilegt framhald af fyrri vörumerkjum. Markmið rannsóknarinnar var að dýpka pekkingu á útvíkkun í ótengda vöruflokka og tengslum slíkrar útvíkkunar við vörumerkjasamband. Kannað var hvaða pættir skýra viðhorf til útvíkkunar við slíkar aðstæður. Eitt verðmætasta vörumerki heims, Apple, var til skoðunar og sem dæmi um útvíkkun í ótengdan vöruflokk voru pátttakendur spurðir um viðhorf til útvíkkunar vörumerkisins i ípróttaskó. Nothæf svör fengust frá 381 pátttakenda með rafrænum spurningalista. Niðurstöðurnar leiddu í ljós jákvæð tengsl milli viðhorfs til útvíkkunar og samsvörunar nýju vörunnar við fyrra vöruframboð. Jafnframt sýndu niðurstöðurnar tengsl milli viðhorfs til útvíkkunar og mats á hæfni fyrirtækisins til að framleiða nýju vöruna. Jákvæð tengsl reyndust einnig vera á milli vörumerkjasambands og viðhorfs til útvíkkunar ásamt pví að vörumerkjasambandið reyndist sterkasti skýringarpáttur á viðhorf neytenda til útvíkkunarinnar í ótengdan vöruflokk.

Abstract: It can be risky to market a new product, but introducing it under a known brand name can reduce the risk. When companies put a new product on the market in a new category under a known brand name it is called brand extension. Extensions into similar categories, or into categories that are in one way or another logically related to the brand, are generally considered more likely to succeed. The aim of the study was to deepen the understanding of brand extension into unrelated categories and the association between this type of extension and brand relationship. Factors explaining consumers' attitudes towards brand extension into an unrelated category were also analyzed. One of the most valuable brands today, Apple, was used as an example and athletic shoes were used as an example of unrelated brand extension. 381 participants answered an electronic questionnaire. The findings revealed a positive relationship between participants' attitude towards brand extension and their view of both the fit of the new product with the brand's previous products and the competence of the company to produce the new product. There was also a positive relationship between attitude towards brand extension and brand relationship. The brand relationship was found to have the most explanatory power in predicting attitude towards brand extension into an unrelated category.

Citation/Tilvísun: Auður Hermannsdóttir og Pálína Mjöll Pálsdóttir, "Útvíkkun vörumerkis og vörumerkjasamband," Samtíð 1 (2013), 5. http://dx.doi.org/10.12742/samtid.2013.5

Received/Móttekið: 2013-07-30. Accepted/Sampykkt: 2013-11-11. Published/Birt: 2013-12-22.

(C) 2013 Authors/Höfundar. This open-access article is published under the terms of the Creative Commons Attribution License, version 3.0/Greinin er birt i opnum aðgangi undir CC-BY 3.0 leyfi (http://creativecommons.org/licenses/by/3.0) 
Útvíkkun vörumerkis og vörumerkjasamband

\section{Inngangur}

Um áratugaskeið hafa vörumerki verið álitin grunnurinn að styrk fyrirtækja og virði peirra í ýmsum atvinnugreinum (Doyle, 2001). Sterk vörumerki geta orðið ein af verðmætustu eignum fyrirtækja (Aaker, 1990; Klink og Smith, 2001) í fjárhagslegum skilningi (Keller og Lehmann, 2006). Fjárhagslegt verðmæti vörumerkja er tilkomið vegna pess eiginleika peirra að geta viðhaldið og aukið tekjur fyrirtækis umfram pær tekjur sem skapast vegna ápreifanlegra eigna (Lane og Jacobson, 1995). Með aðgreiningu frá samkeppnisvörum geta vörumerki aukið virði vara og veitt neytendum ákveðið öryggi í peim ávinningi sem vörumerkið býður upp á (Doyle, 2001).

Pað getur verið áhættusamt að setja nýja vöru á markað. Samkvæmt Gouville (2007) mistekst í 40\% til 90\% tilfella að koma nýrri vöru á framfæri en hlutfallið er mismunandi eftir vöruflokkum. Ein leið til að draga úr áhættunni er að kynna hina nýju vöru undir pekktu vörumerkjaheiti (Jung og Tey, 2010). Slík ákvörðun er byggð á pví að styrkur vörumerkisins og vörumerkjavirðið sem búið er að byggja upp muni hjálpa til við að skapa jákvæða skynjun hjá viðskiptavinum gagnvart nýju vörunni (Nkwocha, Bao, Johnson og Brotspies, 2005) og jafnframt leiða til fjárhagslegs ávinnings fyrir fyrirtækið (Lane og Jacobson, 1995). Pegar fyrirtæki setur á markað nýja vöru í nýjum vöruflokki undir pekktu vörumerki er talað um útvíkkun vörumerkis (e. brand extension) (Aaker og Keller, 1990; Tauber, 1988). Alla jafna er talið heppilegra að útvíkkun eigi sér stað í tengda vöruflokka eða vöruflokka sem á einn eða annan hátt eru taldir eðlilegt framhald af fyrri vöruflokkum (Bottomley og Holden, 2001; Fedorikhin, Park og Thomson, 2008; Jung og Tey, 2010; Nkwocha o.fl., 2005; Tauber, 1988).

Á si̊ðustu áratugum hefur verið algengt að fyrirtæki beiti útvíkkun á vörumerkjum pegar ætlunin er að vaxa. Flestar hafa verið inn í vöruflokka sem hafa ákveðna samsvörun við pá vöruflokka sem vörumerkið er í en ýmsar undantekningar er pó að finna á pví og dæmi um að farið hafi verið með vörumerki inn í gjörólíka vöruflokka. Má til dæmis nefna að undir vörumerkinu Bic sem pekktast er fyrir penna, kveikjara og rakvélar var sett á markað ilmvatn, undir vörumerkinu Uncle Ben's sem pekktast er fyrir hrísgrjón var sett á markað pastasósa og undir Starbucks sem pekktast er fyrir kaffi var settur á markað ís. Sumar slíkar útvíkkanir í ólíka vöruflokka hafa gengið vel, eins og Starbucks ísinn, en Bic-ilmvatnið gekk illa og var fljótlega tekið af markaði (Maoz og Tybout, 2002). Nýlegar rannsóknir hafa sýnt að tengsl viðskiptavina við vörumerki, pað er vörumerkjasamband, hafa áhrif á viðhorf peirra til útvíkkunar pegar samsvörun við fyrri vöruflokka er lítil (Neale, Baazeem og Bougoure, 2009; Spiggle, Nguyen og Caravella, 2012). Pannig kann pað að skipta máli upp á árangur útvíkkunarinnar að vörumerkið hafi gott og sterkt samband við viðskiptavini en 
frekari rannsókna er pörf á pessu sambandi til að renna styrkjari stoðum undir áhrifin og mikilvægið.

Mælingar Interbrand sýna að Apple er verðmætasta vörumerki heims, metið á 98.316 milljónir Bandaríkjadala samkvæmt nýjustu mælingum sem birtar voru haustið 2013. Verðmæti vörumerkisins hefur farið stigvaxandi undanfarin ár en á milli áranna 2012 og 2013 jókst verðmætið um 28\% (Interbrand, 2013) eftir að hafa meira en tvöfaldast milli áranna 2011 og 2012 (Interbrand, 2012). Að mati Goodson (2011) hefur Apple náð góðum árangri í að byggja upp persónuleg tengsl og tryggð viðskiptavina sinna. Petta samband viðskiptavina við vörumerkið hefur leitt til pess að vörumerkið hefur pótt heppilegt til rannsókna par sem vörumerkjasamband er til skoðunar (sjá t.d. Breivik og Thorbjørnsen, 2008; Neale o.fl., 2009). Neale o.fl. (2009) rannsökuðu hvaða áhrif pað hefði á vörumerkjasamband ef vörumerkið Apple væri útvíkkað í tengdan vöruflokk annars vegar og í ótengdan hins vegar. Niðurstöðurnar sýndu að vörumerkjasambandið var sterkara pegar um var að ræða tengdan vöruflokk en ótengdan. Margar af peim rannsóknum sem hafa verið gerðar á útvíkkun hafa meðal annars miðað að pví að kanna hvort samsvörun við fyrri vöruflokka skipti máli (sjá t.d. Batra, Lehmann og Singh, 1993; Bottomley og Holden, 2001; Fedorikhin o.fl., 2008; Jung og Tey, 2010; Nkwocha o.fl., 2005; Tauber, 1988). Niðurstöðurnar hafa yfirleitt leitt í ljós að svo sé en staðreyndin er samt sem áður sú að fyrirtæki velja pessa leið og pví mikilvægt að rannsaka útvíkkun í ótengda vöruflokka betur en gert hefur verið. Рað skiptir til dæmis máli að vita hvað fyrirtæki geta gert til að auka líkur á að slík útvíkkun gangi vel og hvaða pættir pað eru sem skýra viðhorf til hennar en viðhorfið kann að hafa áhrif á kauphegðun viðskiptavina í tengslum við hina nýju vöru. Markmið pessarar rannsóknar er pví að dýpka pekkingu á útvíkkun í ótengda vöruflokka og tengsl slíkrar útvíkkunar við vörumerkjasambandið. Ætlunin er jafnframt að kanna hvaða pættir skýra viðhorf til útvíkkunar við slíkar aðstæður.

Вyrjað verður á að fjalla um útvíkkun vörumerkja almennt og möguleg áhrif slíks fyrir fyrirtæki. Í kjölfarið verður fjallað um vörumerkjasamband og um vörumerkjasamband í samhengi við útvíkkun vörumerkja. Fjallað verður um pá aðferðafræði sem beitt var við rannsóknina og að lokum verða niðurstöður settar fram, pær ræddar í samhengi við fyrri rannsóknir og velt upp með hvaða hætti unnt sé að nýta pær pegar fyrirtæki stefna að útvíkkun í ótengda vöruflokka.

\section{2. Útvíkkun vörumerkja}

Útvíkkun vörumerkis (e. brand extension) á sér stað pegar fyrirtæki setur á markað nýja vöru í nýjum vöruflokki undir nafni núverandi vörumerkis (Aaker og Keller, 1990; Tauber, 1988). Með útvíkkun er vonast til að neytendur yfirfæri pekkingu sína á 
vörumerkinu og pau hugrenningatengsl (e. brand associations) sem vörumerkið kallar fram yfir á nýju vöruna (Nkwocha o.fl., 2005; Reast, 2005). Með peim hætti er búist við að útvíkkunin veiti nýju vörunni ákveðið forskot og styrk sem felst í vitundinni (e. awareness) um vörumerkið (Tauber, 1988). Áhættan sem fylgir pví að setja á markað nýja vöru verður pví oft minni en ella og um leið verða líkurnar á árangri meiri (Aaker, 1990; Smith og Park, 1992; Tauber, 1988). Pegar neytendur hafa jákvætt viðhorf til vörumerkis meta peir útvíkkunina alla jafna á jákvæðari hátt (Aaker og Keller, 1990; Boush og Loken, 1991). Beri neytendur traust til vörumerkisins eru meiri líkur á að peir prófi vöruna par sem traustið á vörumerkinu og sú gæðatrygging sem pað felur í sér bætir upp fyrir vanpekkingu á vörunni (Reast, 2005; Romeo, 1991). Tenging vörumerkisins við gæði er pví einn af lykilpáttum pess að útvíkkunin verði árangursrík (Aaker, 1990).

Í flestum tilvikum er útvíkkun vörumerkis leið fyrirtækja til að fara inn í nýjan vöruflokk með fjárhagslega hagkvæmum hætti (Lane og Jacobson, 1995; Tauber, 1988). Kostnaður við kynningarstarf verður lægri en ella par sem vitund á vörumerkinu er pegar til staðar (Aaker, 1990; Collins-Dodd og Louviere, 1999; Lane og Jacobson, 1995; Smith og Park, 1992; Tauber, 1988). Auk pess nýtur hin nýja vara ávinnings af pví pegar aðrar vörur undir sama vörumerki eru kynntar (Smith og Park, 1992). Kynningarstarf í kringum nýju vöruna getur einnig leitt til aukinnar sölu á vörum móðurvörumerkisins (Balachender og Ghose, 2003; Tauber, 1988).

Ímynd móðurvörumerkisins færist ekki bara yfir á hina nýju vöru heldur gengur pað jafnframt í hina áttina - nýja varan hefur einnig áhrif á ímynd móðurvörumerkisins (Lane og Jacobson, 1995; Magnoni og Roux, 2012; Romeo, 1991). Petta getur pýtt að ef útvíkkunin gengur illa getur pað haft slæm áhrif á vörumerkið í heild (Aaker, 1990) en góð og vandlega útfærð útvíkkun getur styrkt staðfærslu vörumerkisins í hugum neytenda (Park, Jaworski og MacInnis, 1986). Рað er grundvallaratriði að vörumerkið sjálft verði ekki fyrir skaða af útvíkkuninni enda hlýtur markmiðið með henni að vera að styrkja vörumerkið auk pess að nýta virði pess.

Í kjölfar útvíkkunar er líklegt að pað skapist einhver ný hugrenningatengsl við móðurvörumerkið (Aaker, 1990). Nauðsynlegt er að pessi nýju hugrenningatengsl passi við pau sem fyrir eru. Að öðrum kosti getur útvíkkunin dregið úr eða valdið óreiðu á peim hugrenningatengslum sem fyrir voru (Martínez og Pina, 2003). Sérhvert vörumerki kallar fram nokkur hugrenningatengsl. Liu, Hu og Grimm (2010) leggja áherslu á að pegar nokkrar ólíkar vörutegundir bera sama vörumerki sé mikilvægt í kynningarstarfi að nýta pau hugrenningatengsl sem eru mest viðeigandi fyrir hvern vöruflokk fyrir sig. Pannig getur verið heppilegast að draga fram ólíka pætti vörumerkisins við kynningu á ólíkum vörum og pannig draga fram sérstöðu vörumerkisins í sérhverjum vöruflokki. Styrkur vörumerkis í einum vöruflokki er ekki endilega mikil- 
vægasti styrkur pess í öðrum vöruflokki. Mikilvægt er pó að peir pættir sem dregnir eru fram í kynningum á ólíkum vörum stangist ekki á svo að heildarhugrenningatengslin og staðfærsla vörumerkisins í heild verði ekki óskýr.

Sterk viðskiptavinamiðuð vörumerki eru ákjósanlegri, pau veita meira forskot og meiri markaðshlutdeild pegar farið er í útvíkkun en veikari vörumerki (Aaker, 1990; Aaker og Keller, 1990; Maoz og Tybout, 2002; Smith og Park, 1992; Völckner og Sattler, 2006). Með sterku vörumerki er átt við að pað hafi mikla vitund á markaði og búi yfir sterkum, jákvæðum og einstökum tengingum í huga neytenda (Aaker og Keller, 1990). Ekki er pó sjálfgefið að útvíkkun sé heppileg leið pó að vörumerki sé sterkt. Nafn vörumerkisins parf að fela í sér raunverulegt virði innan pess vöruflokks sem farið er inn í (Aaker, 1990). bekkt nafn í ákveðnum vöruflokkum er ekki endilega ávísun á að vel gangi að nýta pað nafn í nýjum vöruflokki. Vörumerkið parf að skapa nýju vörunni aðgreiningu á markaði og forskot - að öðrum kosti kann nýja varan að vera viðkvæm fyrir peirri samkeppni sem er til staðar innan hins nýja vöruflokks (Aaker, 1990).

\subsection{Samsvörun útvíkkunar við fyrri vöruflokka}

Flestir rannsakendur hafa talið að pað purfi að vera góð samsvörun (e. fit) á milli nýju vörunnar og vörumerkisins í huga viðskiptavina (Barone, Miniard og Romeo, 2000; Bottomley og Holden, 2001; Fedorikhin o.fl., 2008; Jung og Tey, 2010; Nkwocha o.fl., 2005; Tauber, 1988). Sumir hafa jafnvel talið að samsvörun auki ekki bara líkur á árangri heldur hafi lítil eða engin samsvörun beinlínis neikvæð áhrif (Boush og Loken, 1991; Fedorikhin o.fl., 2008). Með góðri samsvörun upplifa neytendur nýju vöruna sem rökrétta viðbót við núverandi vöruframboð vörumerkisins (Aaker og Keller, 1990; Keller og Lehmann, 2006; Tauber, 1988). Samsvörun getur í raun verið byggð á hvaða hugrenningatengslum vörumerkisins sem er (Keller og Lehmann, 2006). Pó er talið grundvallaratriði að neytendur hafi trú á hæfni fyrirtækisins til að framleiða viðkomandi vöru (Barone o.fl., 2000; Batra o.fl., 1993) og að samræmi sé á milli ímyndar móðurvörumerkisins og hinnar nýju vöru (Batra o.fl., 1993). Aaker og Kellar (1990) töldu að ef viðskiptavinir hefðu ekki trú á hæfni fyrirtækisins til að framleiða vöruna væri hætta á að tiltrú og traust viðskiptavina til vörumerkisins yfirfærðist ekki á hina nýju vöru. Í kynningum og öllum markaðssamskiptum getur pví verið mikilvægt að leggja áherslu á hæfni fyrirtækisins til að framleiða hina nýju vöru, sér í lagi pegar útvíkkunin er í vöruflokka sem eru ólíkir hefðbundnum vöruflokkum fyrirtækisins (Barone o.fl., 2000). Vegna framangreinds eru eftirfarandi tilgátur settar fram:

- H1: Jákveð tengsl eru á milli mats á samsvörun nýju vörunnar við fyrra vöruframboð og viðhorfs til útvíkkunar vörumerkis 
— H2: Jákvæeð tengsl eru á milli mats á hoefni fyrirtæekisins til að framleiða nýju vöruna og viðhorfs til útvíkkunar vörumerkis

Niðurstöður Smith og Park (1992) bentu pó til pess að samsvörun skipti ekki jafnmiklu máli og áður hafði verið talið. peir vildu pó ekki gera lítið úr mikilvægi samsvörunar en töldu aðstæður og upplýsingar neytenda hafa áhrif á mikilvægið. Niðurstöður Klink og Smith (2001) bentu jafnframt til pess að samsvörun væri hugsanlega ofmetin pví að mikilvægi hennar væri háð páttum sem alla jafna væru ekki metnir í rannsóknum. Klink og Smith (2001) sýndu fram á að áhrif samsvörunar væru að verulegu leyti háð pví hversu miklar upplýsingar neytendur fengju um nýju vöruna og pegar upplýsingarnar væru mjög miklar hefði samsvörunin engin áhrif. Bridges, Keller og Sood (2000) sýndu jafnframt fram á mikilvægi pess að fræða neytendur vel í gegnum markaðssamskipti um tengsl nýju vörunnar við móðurvörumerkið pegar samsvörun væri lítil eða óljós í hugum neytenda. Ef ætlunin er að færa jákvæða eiginleika móðurvörumerkisins yfir á nýju vöruna, sem hlýtur að vera ein af ástæðum pess að varan er markaðssett undir sama vörumerki, er mikilvægt að neytendum sé auðveldað að skynja tengsl móðurvörumerkisins við nýju vöruna (Bridges o.fl., 2000). Arikan (2010) telur að mögulegt sé að búa til tengslin í hugum neytenda með beitingu söluráðanna (e. marketing mix), sér í lagi kynningarstarfsins. Đað hefur einnig reynst hafa jákvæð áhrif á árangur útvíkkunar að beita svokallaðri forkynningu (e. pre-announcement) par sem ýtt er undir væntingar neytenda áður en nýja varan er sett á markað (Liu o.fl., 2010). Sum fyrirtæki hafa farið pessa leið við að undirbyggja væntingar fyrir vörur sem væntanlegar eru á markað, meðal annars er fyrirtækið Apple pekkt fyrir að fara pessa leið. рað hafa pví komið fram sterkar vísbendingar um að vandað kynningarstarf geti bætt að öllu leyti upp fyrir litla eða enga samsvörun. Klink og Smith (2001) töldu einmitt að pessi páttur kynningarstarfsins hefði ekki verið mældur í rannsóknum og gæfu niðurstöðurnar pví ekki endilega raunsanna mynd af mikilvægi samsvörunar.

Pegar hugrenningatengslin sem vörumerki kallar fram byggja á öðrum páttum en vörutengdum páttum, til dæmis lífsstíl eða gæðum, eru meiri líkur á að útvíkkun í ólíka vöruflokka verði árangursrík (Aaker, 1990; Broniarczyk og Alba, 1994). Мeð vönduðum og markvissum markaðssamskiptum er pá hægt að nýta pau hugrenningatengsl sem viðeigandi eru, til dæmis gæði, og skapa pannig samsvörunina við móðurvörumerkið í huga neytenda.

Líta parf á vörumerki og stjórnun á pví sem langtíma fjárfestingu sem ætlunin er að nýta til að ná samskeppnisforskoti til langs tíma (Park o.fl., 1986). Mikilvægt er að hafa ávallt hugfast að efling vörumerkis er ekki markmið í sjálfu sér heldur er um að ræða stefnumiðaða vinnu við að ná grundvallarmarkmiðum fyrirtækja, pað er að skapa verðmæti fyrir hluthafa (Doyle, 2001). Dví er óæskilegt að fara í útvíkkun á vörumerki 
nema ljóst pyki að pað verði vörumerkinu sjálfu til góða til lengri tíma litið og skili sér í auknu verðmæti fyrir hluthafa.

\section{Vörumerkjasamband}

Tengsl (e. attachment) byggjast á tilfinningaböndum sem einstaklingur hefur myndað við ákveðna einingu (Bowlby, 1979). Einstaklingar geta myndað tengsl við aðra einstaklinga en einnig við hluti eins og til dæmis vörumerki og er pá talað um vörumerkjasamband (e. brand relationship) (Fournier, 1998; Schouten og McAlexander, 1995). Viðskiptavinir sem eru í sterku vörumerkjasambandi eru ánægðir með vörumerkið enda er grunnurinn að vörumerkjasambandi jákvæð upplifun og reynsla af vörumerki (O’Loughlin, Szmigin og Turnbull, 2004). Pegar viðskiptavinur hefur myndað slíkt samband við vörumerki hefur hann á vissan hátt persónugert vörumerkið í huga sér og lítur svo á að vörumerkið bæti líf sitt á einhvern hátt (Fournier, 1998; Veloutsou, 2007).

Fournier (1998) setti fram sex vídda BRQ-líkanið um gæði vörumerkjasambands (e. brand relationship quality eða BRQ) sem sjá má á mynd 1. Ástríða (e. love/passion) vísar til styrks og dýptar tilfinningalegu tengsla viðskiptavinarins við vörumerkið. Peir sem bera pessar tilfinningar sterkt í brjósti telja vörumerkið ómissandi og einstakt. Með samsömun (e. self-connection) er átt við áhrif vörumerkisins á sjálfsmynd viðskiptavina. Pegar mikil samsömun er til staðar lítur viðskiptavinurinn á pað sem einhvers konar stöðutákn að eiga vörumerkið. Bönd (e. interdependence) segja til um

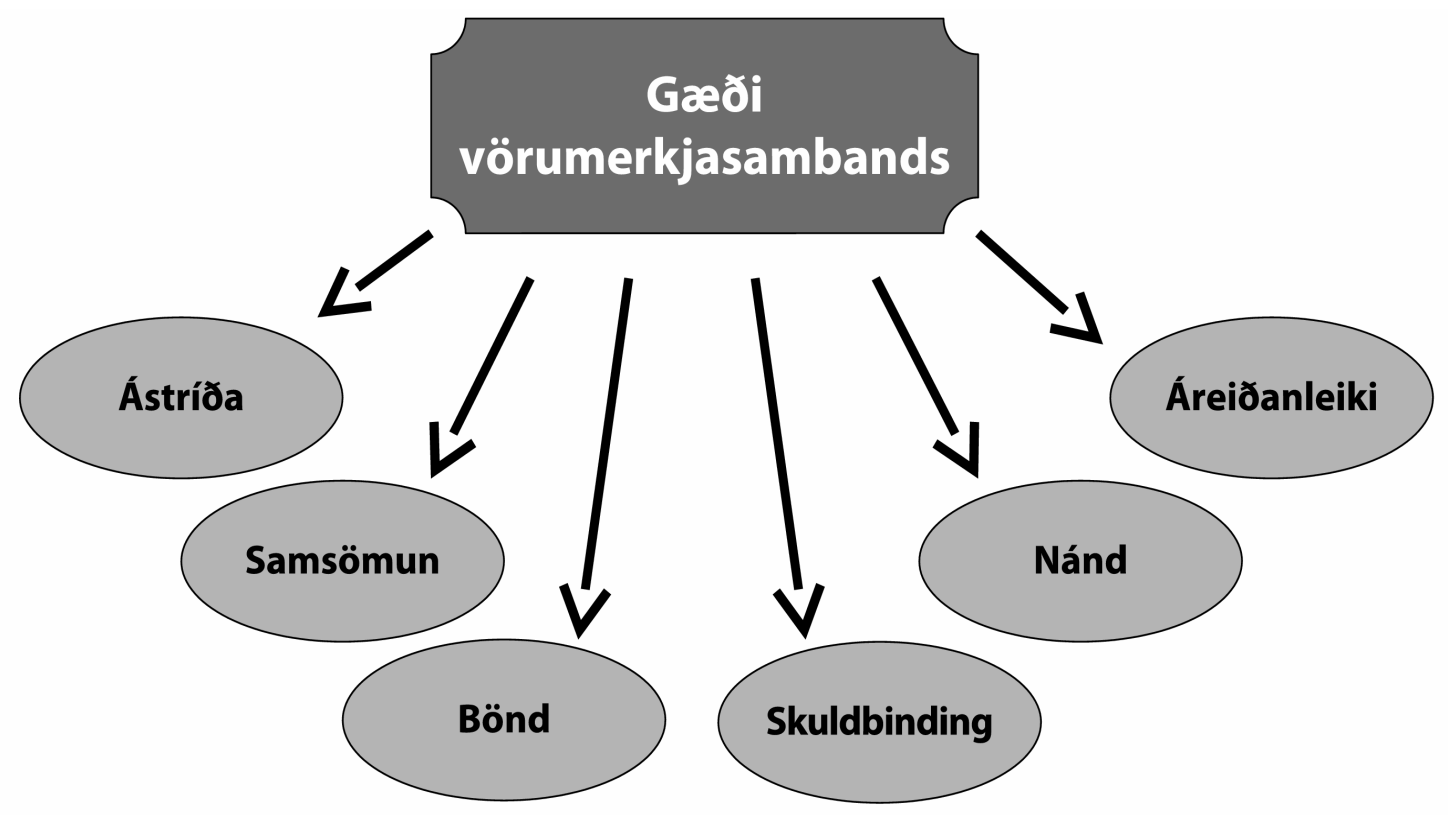

Mynd 1: Sex vídda líkan Fournier um geðði vörumerkjasambands. Heimild: Fournier (1998, bls. 366). 
hversu háðir viðskiptavinir eru vörumerkinu og að hve miklu leyti notkun pess er samtvinnuð daglegu lífi peirra. Skuldbinding (e. commitment) vísar til tryggðar við vörumerkið og áform um áframhaldandi notkun pess. Nánd (e. intimacy) tekur á pví að hve miklu leyti viðskiptavinir skilja hvað vörumerkið stendur fyrir og hversu mikið peir telja að fyrirtækið á bak við vörumerkið skilji hvað peir vilja. Með áreiðanleika (e. brand partner quality) er átt við traust viðskiptavina á pví að vörumerkið muni uppfylla væntingar peirra.

Í BRQ-líkaninu má jafnframt greina tvær yfirvíddir en pær víddir sem eru staðsettar vinstra megin í líkaninu á mynd 1 hallast fremur í átt að tilfinningavíddum á meðan pær víddir sem staðsettar eru hægra megin hallast fremur í átt að hegðunarvíddum (Smit o.fl., 2007). Pannig má segja að út frá skilgreiningu og viðmiðum BRQlíkansins megi segja að vörumerkjasamband sé annars vegar byggt á tilfinningum og hins vegar á hegðun.

Vörumerkjasamband, líkt og önnur tengsl, getur styrkst með tímanum og aukinni tíðni notkunar (Morgan-Thomas og Veloutsou, 2013). Almennt er ákjósanlegt fyrir fyrirtæki að ná sterku vörumerkjasambandi við viðskiptavini sína enda er slíkt samband talið fela í sér mikið virði fyrir fyrirtækið og er talið ein af forsendum langvarandi tryggðar peirra (Aaker og Keller, 1990; Papista og Dimitriadis, 2012; Park, Kim og Kim, 2002). Viðskiptavinir í sterku vörumerkjasambandi eru líklegri til að vera öflugir talsmenn fyrirtækisins, peir horfa síður til samkeppnisaðila og eru viljugri til að fyrirgefa vörumerkinu mistök (Curasi og Kennedy, 2002). Pessir viðskiptavinir eru jafnframt tilbúnari til að deila persónulegum upplýsingum um sjálfa sig með fyrirtækinu sem stendur á bak við vörumerkið (Smit o.fl., 2007) en slíkar upplýsingar eru alla jafna verðmætar fyrirtækjum í markaðsstarfi. Sterkt vörumerkjasamband er jafnframt talið hafa jákvæð áhrif á viðhorf til útvíkkunar á vörumerkinu og par með á kauphegðun á nýju vörunni og hversu hátt verð peir eru tilbúnir að greiða fyrir hana (Fedorikhin o.fl., 2008; Iversen og Hem, 2011; Maoz og Tybout, 2002). Viðskiptavinir í sterku sambandi eru jafnvel tilbúnir til að leggja mikið á sig til að nálgast vörur sem tilheyra vörumerkinu (Curasi og Kennedy, 2002). Peir eiga yfirleitt auðveldara með að kalla fram í hugann vörumerkjatengingar pegar peir heyra minnst á vörumerkið og yfirfæra pær á nýju vöruna (Park o.fl., 2002). Út frá framangreindu er eftirfarandi tilgáta sett fram:

- H3: Jákveðð tengsl eru á milli vörumerkjasambands og viðhorfs til útvíkkunar vörumerkis 


\section{Aðferð}

\subsection{Pátttakendur}

Notast var við tvær úrtaksaðferðir; rafrænt hentugleikaúrtak meðal nemenda Háskóla Íslands og snjóboltaúrtak á samfélagsmiðli. Internetið er í auknum mæli notað við fyrirlagnir á könnunum og er líklegt að pað verði enn algengara á komandi árum enda er talið að ókostirnir sem póttu fylgja peirri aðferð séu ekki lengur til staðar (sjá Hunter, 2012). Algengt er að nota úrtak háskólanemenda í sambærilegum rannsóknum (sjá t.d. Jung og Tey, 2010; Klink og Smith, 2001; Liu o.fl., 2010; Maoz og Tybout, 2002; Nkwocha o.fl., 2005) en til að auka fjölda og margbreytileika pátttakenda var jafnframt beitt rafrænu snjóboltaúrtaki í gegnum samfélagsmiðilinn Facebook. Notkun Facebook við rafræna fyrirlögn er talin heppileg leið, sér í lagi pegar beita á snjóboltaúrtaki par sem svarhlutfall hefur reynst hærra með peirri aðferð en pegar hefðbundnara rafrænu snjóboltaúrtaki er beitt (Baltar og Brunet, 2012).

par sem rannsókninni var meðal annars ætlað að mæla vörumerkjasamband var pað viðmið sett að peir sem tækju pátt pyrftu að hafa notað Apple-vörur í að lágmarki sex mánuði fyrir fyrirlögn. Petta viðmið var sett fram til að tryggja að pátttakendur hefðu ákveðna reynslu af notkun vörumerkisins og hefðu um leið haft tækifæri til að mynda ákveðið samband við vörumerkið. Til að sía burt pá sem ekki uppfylltu pað viðmið voru notaðar tvær spurningar. Annars vegar var pað fyrsta spurningin par sem spurt var hvort pátttakendur hefðu notað Apple-vörur síðastliðna sex mánuði. Svarkostir voru prír; já, nei og veit ekki. beir sem svöruðu nei og veit ekki voru síaðir út með pví að vísa peim beint í bakgrunnsbreytur og svöruðu peir pví ekki spurningalistanum að öðru leyti. Af peim 497 sem hófu pátttöku svöruðu 402 pví til að peir hefðu notað Apple-vörur síðastliðna sex mánuði. Seinni síuspurningin var í bakgrunnsbreytunum par sem spurt var um lengd notkunar Apple-vara. Einn af svarkostunum var „skemur en 6 mánuði“. Alls merktu 19 einstaklingar við pann svarkost og tveir slepptu pví að svara spurningunni. Báðir pessir hópar voru síaðir út við greiningu. Eftir stóðu pví svör frá 381 pátttakenda sem notuð voru við greiningu gagnanna. Töluvert fleiri konur tóku pátt $(66,9 \%)$ en karlar (33,1\%). Í töflu 1 má sjá frekari upplýsingar um bakgrunn pátttakenda.

\subsection{Mælitæki}

Mælitækið samanstóð af tveimur undirkvörðum auk síuspurninga og bakgrunnsspurninga. Annar undirkvarðinn miðaði að mælingum á vörumerkjasambandi pátttakenda við Apple og samanstóð af 16 atriðum og hinn snéri að útvíkkun á vörumerkinu og samanstóð af 7 atriðum. 
Tafla 1: Bakgrunnsupplýsingar um pátttakendur.

\begin{tabular}{|c|c|c|c|}
\hline \multicolumn{2}{|c|}{ Fjöldi Apple-vara í notkun } & \multicolumn{2}{|l|}{ Lengd notkunar } \\
\hline Ein vara & $36,9 \%$ & Innan við 1 ár & $9,2 \%$ \\
\hline Tvær vörur & $33,0 \%$ & 1 ár upp að 2 árum & $6,8 \%$ \\
\hline Prjár vörur & $20,3 \%$ & 2 ár upp að 3 árum & $13,4 \%$ \\
\hline Fjórar vörur & $4,3 \%$ & 3 ár upp að 5 árum & $16,3 \%$ \\
\hline Fimm vörur eða fleiri & $5,5 \%$ & 5 ár eða lengur & $54,3 \%$ \\
\hline \multicolumn{2}{|l|}{ Aldur } & \multicolumn{2}{|l|}{ Tíðni notkunar } \\
\hline 29 ára eða yngri & $58,7 \%$ & Daglega & $75,3 \%$ \\
\hline 30 til 39 ára & $24,2 \%$ & Einu sinni til sex sinnum í viku & $17,8 \%$ \\
\hline 40-49 ára & $9,2 \%$ & Einu sinni til prisvar sinnum í mánuði & $3,9 \%$ \\
\hline 50 ára eða eldri & $7,9 \%$ & Sjaldnar en mánaðarlega & $2,9 \%$ \\
\hline
\end{tabular}

Við mælingu á vörumerkjasambandi var stuðst við mælitæki sem próað var af Thorbjørnsen o.fl. (2002) en síðan endurbætt af Xie og Heung (2012). Mælitækið mælir gæði vörumerkjasambandsins út frá BRQ-líkani Fournier (1998) um sex víddir vörumerkjasambands. Líkan Fournier (1998) hefur áđur verið til grundvallar í rannsóknum á vörumerkjasambandi (sjá t.d. Breivik og Thorbjørnsen, 2008; Neale o.fl., 2009; Park o.fl., 2002; Smit o.fl., 2007). Mælitæki Xie og Heung (2012) samanstóð af 25 fullyrðingum en peim var fækkað í 16 til pess að forðast að heildarfjöldi atriða í mælitækinu yrði pað mikill að hann drægi mögulega úr pátttökuvilja. Teknar voru út pær fullyrðingar sem höfundum pótti svipa mjög til annarra.

Ætlunin var að kanna viðhorf til útvíkkunar með lítið samræmi við fyrri vöruflokka. Í pví skyni var ákveðið að kanna viðhorf til útvíkkunar Apple í ípróttaskó en vöruflokkurinn skór var notaður sem dæmi um framlengingu Apple-vara í vöruflokk með litla samsvörun hjá Neale o.fl. (2009). Ípróttaskór voru valdir en ekki bara skór almennt til að gefa pátttakendum nákvæmari hugmyndir um vöruflokkinn sem ætlast var til að peir hugsuðu um við svörun og par með auka líkur á að pátttakendur væru með sambærilega vöru í huga. Vert er að taka fram að árið 2006 hófst sala á ípróttaskóm sem Apple, í samvinnu við Nike, setti á markað undir heitinu Nike + (Nike plus). pessir skór hafa pá eiginleika að geta „talað við“ iPod-spilara par sem nemi í skónum sendir skilaboð í iPod um til dæmis vegalengd sem farin er, hversu hratt er farið og fjölda hitaeininga sem er brennt. Pó að vörumerkjaheiti Nike sé meira áberandi í tengslum við vöruna eru tákn (e. logo) beggja vörumerkja á vörunni sjálfri og bæði fyrirtækin kynna vöruna. Í kjölfar tilkynningar um að Nike + væri væntanlegt á markað hækkuðu hlutabréf í Apple um 1,5\% (CNN Money, 2006) sem bendir til pess að markaðurinn hafi haft trú á að fyrirtækið myndi njóta góðs af pví að setja vöruna á 
markað. Varan sem notuð er sem dæmi um útvíkkun í pessari rannsókn er ekki fyllilega sambærileg við Nike + enda gert ráð fyrir að viðkomandi skór yrðu eingöngu markaðssettir undir vörumerkjaheiti Apple. Tilvist Nike + og sú staðreynd að Apple var tilbúið að setja vöruna á markað í samvinnu við pekkt vörumerki sem er starfrækt á ípróttavörumarkaðnum sýnir pó að ekki er fjarstæðukennt að taka ípróttaskó sem dæmi um útvíkkun á vörum Apple.

Við samningu atriða varðandi viðhorf til útvíkkunar var horft til fyrri rannsókna á viðfangsefninu (Aaker og Keller, 1990; Oakley, Duhachek, Balachander og Sriram, 2008; Reast, 2005). Pátttakendur voru beðnir um að meta hversu líklegt pað væri að peim myndi líka við Apple-ípróttaskó, kaupa pá og velja pá umfram sambærilegar vörur á markaði.

Við mælingu á samræmi á milli útvíkkunar í vöruflokkinn ípróttaskó og vörumerkisins Apple voru pátttakendur beðnir að svara pví hversu vel peir tengdu góða hönnun við núverandi Apple-vörur annars vegar og við Apple-ípróttaskó hins vegar. Spurningarnar tóku mið af rannsóknum Broniarczyk og Alba (1994) og Spiggle o.fl. (2012). Ástæðan fyrir pví að pessi vörumerkjatenging var notuð er sú að Apple-vörur eru pekktar fyrir góða hönnun (Wiskus, 2013) og talið var að pau hugrenningatengsl gætu færst yfir á ípróttaskóna. Að lokum voru pátttakendur beðnir um að taka afstöðu til hversu vel peim pótti varan passa við núverandi vöruframboð Apple og hversu mikla hæfni peir töldu fyrirtækið Apple hafa til pess að framleiða ípróttaskó. Spurningarnar eru í samræmi við fyrri rannsóknir á tengslum milli útvíkkunar og vörumerkis (Aaker og Keller, 1990; Völckner og Sattler, 2006).

Pó að líklegt sé að gæði og verð vörunnar hafi töluverð áhrif á viðhorf vildu rannsakendur draga úr áhrifum pessara pátta og pví var vöruflokkurinn aðeins nefndur en ekki greint frá gæðum eða verði. Ástæðan fyrir pví er að fyrsti snertiflötur viðskiptavina við nýjar vörur er oft í formi markaðsaðgerða sem veita mjög takmarkaðar upplýsingar um vöruna, til dæmis á auglýsingaskiltum eða í hulduauglýsingum (e. mystery advertisements) og pví var að einhverju leyti líkt eftir peim aðstæðum (Monga og John, 2010).

Notast var við sjö punkta Likert kvarða í öllum mælingum líkt og algengt er í rannsóknum á viðfangsefninu (Oakley o.fl., 2008; Smit o.fl., 2007; Thorbjørnsen o.fl., 2002; Völckner og Sattler, 2006). I öllum tilvikum táknaði 1 jákvæðasta svarkost og 7 neikvæðasta svarkost.

Spurningalistinn var forprófaður á fimm einstaklingum á ólíkum aldri og af báðum kynjum til að kanna skilning. Engar athugasemdir voru gerðar og pví talið að skilningur á merkingu atriða væri góður. 


\subsection{Framkvæmd}

Spurningalistinn var settur upp með rafrænum hætti og var tengill á könnunina sendur í gegnum nemendaskrá Háskóla Îslands og í gegnum Facebook. Á upphafssíðu könnunarinnar var pátttakendum greint frá pví að markmiðið væri að kanna viðhorf til vörumerkisins Apple og greint frá að svör yrðu ekki rakin til pátttakenda. Söfnun gagna fór fram á fyrri hluta árs 2013.

\section{Niðurstöður}

Niðurstöður atriða varðandi útvíkkun vörumerkisins Apple í ípróttaskó má sjá í töflu 2. Líkt og sjá má telja pátttakendur almennt frekar ólíklegt að peim myndu líka við ípróttaskóna, kaupa pá eða velja umfram aðra ípróttaskó á markaðnum. Pví má draga pá ályktun að viðhorf til útvíkkunar Apple-vara í jafnótengdan vöruflokkog ípróttaskó yrði frekar neikvætt. Almennt telja pátttakendur hönnun á Apple-vörum vera mjög góða, líkt og gert var ráð fyrir og peir virðast hallast í að pví að ípróttaskórnir verði jafnframt vel hannaðir. Miðlungssterk jákvæð tengsl reyndust vera á milli mats fólks á gæðum hönnunar Apple-vara og trú peirra á að ípróttaskór frá Apple yrðu vel hannaðir $(r(369)=0,442 ; p<0,001)$. Út frá pessu má búast við að hugrenningatengsl viðskiptavina við gæði í tengslum við vörumerkið Apple myndu færast yfir á hina nýju

Tafla 2: Niðurstöður breyta sem lúta að útvíkkun.

\begin{tabular}{|c|c|c|c|}
\hline Breytur & $\mathrm{M}$ & sf & $\mathrm{N}$ \\
\hline $\begin{array}{l}\text { Hversu ólíklegt eða líklegt telur pú að pér muni líka við } \\
\left.\text { Apple-ípróttaskó? }{ }^{*}\right)\end{array}$ & 3,06 & 1,55 & 378 \\
\hline $\begin{array}{l}\text { Hversu ólíklegt eða líklegt er að pú mundir kaupa } \\
\text { Apple-ípróttaskó? }\left(^{*}\right)\end{array}$ & 2,49 & 1,46 & 377 \\
\hline $\begin{array}{l}\text { Hversu ólíklegt eða líklegt er að pú mundir velja } \\
\text { Apple-ípróttaskó umfram aðra ípróttaskó á } \\
\text { markaðnum? }\left(^{*}\right)\end{array}$ & 2,44 & 1,40 & 376 \\
\hline $\begin{array}{l}\text { Hversu illa eða vel hannaðar telur pú núverandi vörur frá } \\
\text { Apple vera? }(\dagger)\end{array}$ & 6,01 & 1,05 & 377 \\
\hline $\begin{array}{l}\text { Hversu illa eða vel hannaða telur pú að Apple-ípróttaskór } \\
\text { myndu vera? }(\dagger)\end{array}$ & 4,59 & 1,35 & 373 \\
\hline $\begin{array}{l}\text { Hversu illa eða vel finnst pér Apple-ípróttaskór passa við } \\
\text { núverandi vöruframboð Apple? }(\dagger)\end{array}$ & 1,99 & 1,22 & 380 \\
\hline $\begin{array}{l}\text { Hversu litla eða mikla hæfni telur pú fyrirtækið Apple hafa } \\
\text { til pess að framleiða ípróttaskó? ( })\end{array}$ & 3,01 & 1,52 & 378 \\
\hline $\begin{array}{l}\left({ }^{*}\right) \text { Mjög ólíklegt }=1 \text {, Mjög líklegt = } \\
(\dagger) \text { Mjög illa }=1, \text { Mjög vel = } 7 \\
(\ddagger) \text { Mjög litla }=1, \text { Mjög mikla }=7\end{array}$ & & & \\
\hline
\end{tabular}


vöru en pó virðast pátttakendur telja fyrirtækið hafa fremur litla hæfni til að framleiða ípróttaskó. Niðurstöðurnar staðfesta pað sem höfundar bjuggust við; að ípróttaskór teljast vera með lítið samræmi við núverandi vörur Apple.

Fyrstu prjár breyturnar í töflu 2 voru sameinaðar í eina breytu sem ætlað var að meta viðhorf til útvíkkunar. Áreiðanleiki samsettu breytunnar var góður $(\alpha=0,908)$. Viðhorf til útvíkkunar vörumerkisins í ípróttaskó reyndist neikvæðara meðal karla (M $=2,14 ; \mathrm{sf}=1,31 ; \mathrm{N}=123)$ en kvenna $(\mathrm{M}=2,90 ; \mathrm{sf}=1,30 ; \mathrm{N}=245)(\mathrm{t}(366)=-5,23 ; p<$ $0,001)$. Peir sem nota færri Apple-vörur eru almennt með nokkuð neikvæðara viðhorf til útvíkkunar en peir sem nota fleiri vörur vörumerkisins $(F(4,366)=3,85 ; p<0,005)$ og pví oftar sem einstaklingar nota Apple-vörur pví jákvæðari eru peir gagnvart útvíkkuninni $(F(3,369)=8,56 ; p<0,001)$.

Miðlungssterk jákvæð tengsl reyndust vera milli viðhorfa til útvíkkunar og annars vegar pess hversu vel ípróttaskórnir póttu passa við vöruframboð Apple, pað er að segja samsvörun $(r(371)=0,390 ; p<0,001)$ og hins vegar hversu mikla hæfni fyrirtækið var talið búa yfir til að framleiða ípróttaskó $(r(369)=0,368$; $p<0,001)$. Samkvæmt pví er viðhorfið jákvæðara eftir pví sem hin nýja vara er talin passa betur við fyrra vöruframboð og eftir pví sem fyrirtækið er talið búa yfir meiri hæfni til að framleiða hina nýju vöru.

Í töflu 3 má sjá niðurstöður atriða sem mátu vörumerkjasamband pátttakenda við Apple. Um er að ræða sex víddir og eins og sjá má í töflunni var áreiðanleiki víddanna í öllum tilvikum ásættanlegur að undanskilinni víddinni samsömun par sem hann náði ekki pví viðmiði sem Nunnally (1978) mælir með. Hugsanlega hefði purft að hafa fleiri atriði í peirri vídd og mælst er til að pað verði gert í frekari rannsóknum. Prátt fyrir að áreiðanleikinn hafi ekki verið jafnmikill og æskilegt hefði verið var pó ákveðið að nýta víddina með fyrirvara um lágan áreiðanleika. Út frá öllum breytunum var búin til samsetta breytan vörumerkjasamband $(\mathrm{M}=4,85 ; \mathrm{sf}=1,29 ; \mathrm{N}=350)$ og reyndist áreiðanleiki peirrar samsettu breytu mjög góður $(\alpha=0,955)$.

Nokkur munur var á styrk vörumerkjasambands eftir bakgrunnsbreytum. Pannig reyndust konur $(\mathrm{M}=5,08 ; \mathrm{sf}=1,19 ; \mathrm{N}=228)$ vera í sterkara sambandi við vörumerkið en karlar $(M=4,41 ; s f=1,36 ; N=116)(t(206)=-4,57 ; p<0,001)$. Vörumerkjasambandið er sterkara eftir bví sem einstaklingar nota fleiri vörur frá Apple $(F(4,343)=$ 43,56; $p<0,001)$, hafa notað vörurnar lengur $(F(4,345)=4,73 ; p=0,001)$ og pví oftar sem pær eru notaðar $(F(3,346)=54,54 ; p<0,001)$. Líkt og sjá má í töflu 4 eru pað helst fjöldi Applevara sem notaðar eru og tíðni notkunar sem skýra vörumerkjasambandið. Heildaráhrif líkansins reyndust marktæk $(F(5,335)=52,65 ; p<0,001)$ og dreifing breytanna skýrði samanlagt 44,0\% af dreifingu vörumerkjasambandsins. 
Tafla 3: Niðurstöður breyta sem lúta að vörumerkjasambandi.

\begin{tabular}{lrrr}
\hline & $\mathrm{M}$ & sf & $\mathrm{N}$ \\
\hline Ástríða: $\alpha=0,880$ & 4,65 & 1,58 & 76 \\
Mér pykir mjög vænt um Apple-vörurnar mínar & 5,13 & 1,62 & 379 \\
Mér finnst Apple-vörurnar passa mér mjög vel & 4,91 & 1,65 & 378 \\
Ég tengist Apple sterkari böndum en öðrum vörumerkjum & 3,93 & 1,98 & 379 \\
\hline Samsömun: $\alpha=0,644$ & 3,65 & 1,37 & 375 \\
Ég tel mig eiga ýmislegt sameiginlegt með öðrum Apple-notendum & 4,24 & 1,48 & 376 \\
Pað að ég noti Apple-vörur gefur til kynna hvernig einstaklingur ég er & 3,06 & 1,70 & 379 \\
\hline Bönd: $\alpha=0,865$ & 4,82 & 1,63 & 373 \\
Ég er orðin/n mjög vön/vanur pví að hafa vörur frá Apple í kringum mig & 5,63 & 1,60 & 378 \\
Pað væri slæmt ef ég pyrfti að skipta yfir í önnur vörumerki & 4,19 & 2,09 & 378 \\
Alltaf pegar ég nota vörur frá Apple er ég minnt/ur á hversu mikið mér líkar & 4,60 & 1,76 & 379 \\
$\quad$ við vörurnar & & & \\
\hline Skuldbinding: $\alpha=0,848$ & 5,01 & 1,76 & 377 \\
Ég mun halda áfram að nota Apple-vörur í framtíðinni & 5,61 & 1,66 & 379 \\
Ég er tilbúin/n til að færa ákveðnar fórnir (t.d. í formi tíma og peninga) til að & 4,40 & 2,08 & 379 \\
$\quad$ eignast og nota Apple-vörur & & & \\
\hline Nánd: $\alpha=0,801$ & 5,07 & 1,33 & 373 \\
Ég tel mig skilja hvað Apple-vörumerkið stendur fyrir & 5,26 & 1,37 & 378 \\
Ég tel að fyrirłækið Apple skilji hvað ég vil & 4,71 & 1,66 & 377 \\
Ég tel að Apple-vörurnar uppfylli parfir mínar & 5,25 & 1,66 & 379 \\
\hline Áreiðanleiki: $\alpha=0,834$ & 5,59 & 1,16 & 377 \\
Fyrirtækið Apple stendur við loforð sín & 5,30 & 1,29 & 381 \\
Ég veit við hverju er að búast af Apple-vörum & 5,81 & 1,21 & 378 \\
Apple-vörurnar hafa alltaf reynst mér vel & 5,64 & 1,52 & 380 \\
\hline
\end{tabular}

Mjög ósammála = 1, Mjög sammála = 7

Tafla 4: Skýringarmáttur breyta á vörumerkjasambandi við Apple.

\begin{tabular}{|c|c|c|c|c|c|}
\hline & \multicolumn{2}{|c|}{ Óstaðlaðir hallastuðlar } & \multicolumn{3}{|c|}{ Staðlaðir hallastuðlar } \\
\hline & $\mathrm{B}$ & Staðalvilla & $\beta$ & $\mathrm{t}$ & $\mathrm{p}$ \\
\hline Fasti & 3,792 & 0,371 & & 10,234 & 0,000 \\
\hline Fjöldi Applevara í notkun & 0,424 & 0,052 & 0,375 & 8,233 & 0,000 \\
\hline Tíðni notkunar Applevara & $-0,653$ & 0,084 & $-0,354$ & $-7,767$ & 0,000 \\
\hline Lengd notkunar Applevara & 0,076 & 0,040 & 0,079 & 1,899 & 0,058 \\
\hline Kyn & 0,473 & 0,114 & 0,175 & 4,159 & 0,000 \\
\hline Aldur & $-0,073$ & 0,056 & $-0,054$ & $-1,303$ & 0,194 \\
\hline
\end{tabular}


Tengsl vörumerkjasambands og viðhorfs til útvíkkunar reyndust miðlungssterk og jákvæð $(r(371)=0,432 ; p<0,001)$. Tengsl reyndust vera milli allra vídda vörumerkjasambands og viðhorfs til útvíkkunar $(r=0,339-0,390 ; p<0,001)$.

Í töflu 5 má sjá að vörumerkjasambandið skýrir stærstan hluta af viðhorfi til útvíkkunar á vörumerkinu Apple. Næst á eftir kemur viðhorf til pess hvernig nýja varan samræmist fyrri vörum og trú fólks á gæðum hönnunar ípróttaskónna. Heildaráhrif líkansins voru marktæk $(F(8,325)=26,85 ; p<0,001)$ og skýrði dreifing breytanna samanlagt 39,8\% af dreifingu í viðhorfi til útvíkkunar á vörumerkinu Apple í vöruflokkinn ípróttaskór.

Tafla 5: Skýringarmáttur breyta á viðhorfi til útvíkkunar vörumerkisins Apple.

\begin{tabular}{|c|c|c|c|c|c|}
\hline & \multicolumn{2}{|c|}{ Óstaðlaðir hallastuðlar } & \multicolumn{3}{|c|}{ Staðlaðir hallastuðlar } \\
\hline & B & Staðalvilla & $\beta$ & $\mathrm{t}$ & $\mathrm{p}$ \\
\hline Fasti & $-0,222$ & 0,475 & & $-0,466$ & 0,641 \\
\hline Vörumerkjasamband & 0,418 & 0,072 & 0,392 & 5,773 & 0,000 \\
\hline Mat á hönnunargæðum Applevara & $-0,139$ & 0,077 & $-0,106$ & $-1,814$ & 0,071 \\
\hline Vænt hönnunargæði ípróttaskónna & 0,238 & 0,051 & 0,238 & 4,669 & 0,000 \\
\hline Mat á samræmi útvíkkunar við fyrra vöruframboð & 0,317 & 0,057 & 0,285 & 5,575 & 0,000 \\
\hline Mat á hæfni Apple til að framleiða ípróttaskó & 0,084 & 0,047 & 0,093 & 1,783 & 0,075 \\
\hline Fjöldi Applevara í notkun & $-0,004$ & 0,063 & $-0,003$ & $-0,064$ & 0,949 \\
\hline Tíðni notkunar Applevara & $-0,082$ & 0,102 & $-0,041$ & $-0,798$ & 0,426 \\
\hline Lengd notkunar Applevara & $-0,037$ & 0,045 & $-0,036$ & $-0,807$ & 0,420 \\
\hline
\end{tabular}

\section{Umræður}

Vörumerki geta verið meðal verðmætustu eigna sérhvers fyrirtækis vegna pess fjárhagslega verðmætis sem pau geta skapað fyrirtækjum. Мeð vandaðri vörumerkjastjórnun er mögulegt að skapa sterk vörumerki og ná sterkri aðgreiningu á markaði sem getur skapað fyrirtækjum forskot á samkeppnisaðila. Vegna pessa er oft miklum tíma og peningum varið í að efla vörumerki. Pegar fyrirtæki ætla sér að vaxa getur verið skynsamlegt að nýta pá fjárfestingu og pað virði sem skapað hefur verið í vörumerkinu með pví að fara í vörumerkjaútvíkkun. Vörumerkjaútvíkkun á pó hugsanlega ekki alltaf við og hafa rannsóknir sýnt að heppilegast sé að samsvörun sé á milli pess vöruflokks sem útvíkkað er í og peirra vöruflokka sem vörumerkið hefur tilheyrt áður (Barone o.fl., 2000; Bottomley og Holden, 2001; Jung og Tey, 2010; Nkwocha o.fl., 2005). Útvíkkun í vöruflokka sem kunna að virðast ótengdir getur pví verið áhættusöm og varhugaverð. Rannsóknir hafa bent til pess að viðskiptavinir í sterku vörumerkjasambandi séu almennt jákvæðari gagnvart vörumerkjaútvíkkun en aðrir (Fedorikhin o.fl., 2008; Iversen og Hem, 2011; Maoz og Tybout, 2002). Með rannsókninni var 
ætlunin að kanna hvaða pættir skýra viðhorf til útvíkkunar á vörumerki pegar farið er inn í vöruflokk sem er ólíkur fyrri vöruflokkum vörumerkisins.

Út frá niðurstöðunum má búast við að útvíkkun í jafnótengdan vöruflokk og ípróttaskór eru í tilfelli Apple yrði ekki sérlega vel tekið af neytendum. Viðhorfið reyndist ekki jákvætt og leiða má að pví líkum að útvíkkunin myndi ekki ganga mjög vel. Pó ber að hafa í huga að niðurstöðurnar gefa vísbendingar um að hugrenningatengsl um gæði myndu yfirfærast á nýju vöruna og pví væri hugsanlegt að með góðu kynningarstarfi par sem lögð væri áhersla á pau hugrenningatengsl væri hægt að ná góðum árangri með slíka útvíkkun.

Jákvæð tengsl reyndust vera milli samsvörunar nýju vörunnar að mati pátttakenda og viðhorfs peirra til útvíkkunar á vörumerkinu og er tilgáta 1 pví studd. Petta er í samræmi við fyrri rannsóknir par sem niðurstöður hafa bent til pess að viðhorf til útvíkkunar sé jákvæðara ef samræmið er gott milli nýju vörunnar og peirra vara sem áður hafa verið markaðssettar undir vörumerkinu (Barone o.fl., 2000; Bottomley og Holden, 2001; Fedorikhin o.fl., 2008; Jung og Tey, 2010; Nkwocha o.fl., 2005; Tauber, 1988). Раð hvort samræmi er til staðar að mati neytenda og hversu mikið pað er byggir á peim hugrenningatengslum sem neytendur hafa gagnvart vörumerkinu. Hugrenningatengslin geta verið byggð á vörutengdum páttum eða öðrum páttum eins og til dæmis gæðum. Ef fara á í útvíkkun í vöruflokk sem alla jafna telst ekki hafa mikið samræmi við fyrri vöruflokka vörumerkisins getur verið heppilegt í kynningarstarfi að leggja áherslu á hugrenningatengsl sem byggja fremur á öðrum páttum en vörutengdum páttum (Aaker, 1990; Brioniarczyk og Alba, 1994). Мeð vönduðum markaðssamskiptum getur fyrirtækið haft áhrif á og auðveldað neytendum að mynda tengslin milli nýju vörunnar og móðurvörumerkisins (Bridget o.fl., 2000). Par sem niðurstöður pessarar rannsóknar og fyrri rannsókna sýna jákvæð tengsl milli samsvörunar og viðhorfa til útvíkkunar er mikilvægt að fyrirtæki leggi áherslu á að kynna fyrir neytendum pá samsvörun sem er til staðar á milli nýju vörunnar og móðurvörumerkisins. Pegar samsvörunin byggir á öðrum páttum en vörutengdum páttum kann að vera mikilvægara en ella að benda á pessa samsvörun. Niðurstöður Klink og Smith (2001) bentu til pess að með öflugu kynningarstarfi væri jafnvel hægt að bæta að öllu leyti upp fyrir litla eða enga samsvörun.

Jákvæð tengsl reyndust vera á milli hæfni fyrirtækisins til að framleiða nýju vöruna að mati pátttakenda og viðhorfa peirra til útvíkkunar. Tilgáta 2 er pví studd. Pessi niðurstaða styður pað sem meðal annars Aaker og Keller (1990), Barone o.fl. (2000) og Batra o.fl. (1993) lögðu áherslu á, pað er að pað sé grundvallaratriði í útvíkkun á vörumerki að neytendur hafi trú á hæfni fyrirtækisins til að framleiða viðkomandi vöru. Í pessu sambandi er mikilvægt að huga að kynningarstarfinu í kringum hina nýju vöru. Rétt eins og mikilvægt er að draga fram samræmið við fyrri 
vöruflokka í kynningum er mikilvægt að sannfæra neytendur um hæfni fyrirtækisins til að framleiða vöruna. Petta á sérstaklega við pegar útvíkkun er í lítið tengda eða ótengda vöruflokka (Barone o.fl., 2000).

Jákvæð tengsl reyndust vera á milli vörumerkjasambands og viðhorfa til útvíkkunar á vörumerkinu og er tilgáta 3 pví studd. Niðurstöðurnar sýna jafnframt að vörumerkjasambandið er sá páttur sem skýrir mest af viðhorfi neytenda til útvíkkunar á Apple í ótengdan vöruflokk. Pað er í samræmi við niðurstöður Fedorikhin o.fl. (2008), Iversen og Hem (2011) og Maoz og Tybout (2002). Ef vörumerki ætla sér að vaxa með útvíkkun í ótengda vöruflokka getur pví verið mikilvægt að vinna að öflugu vörumerkjasambandi við viðskiptavini til að auka líkur á velgengni útvíkkunarinnar. Ávallt ætti pó að hafa í huga pær fjölmörgu rannsóknir sem hafa sýnt að útvíkkun í vöruflokka með samræmi við fyrri vöruflokka sé heppilegri og vænlegri til árangurs.

\section{Takmarkanir og tillögur að frekari rannsóknum}

Rannsóknin tók aðeins til eins vörumerkis og pví verður að horfa á yfirfærslu niðurstaðna fyrir önnur vörumerki í pví ljósi. Nauðsynlegt er að gera frekari rannsóknir á viðfangsefninu og væri pá ákjósanlegt að taka til skoðunar fleiri vörumerki og ólík stig samræmingar, pað er útvíkkanir í tengda vöruflokka, minna tengda vöruflokka, lítið tengda vöruflokka og ótengda vöruflokka. Auk pessa var ekki tekið tillit til kynningarstarfs enda erfitt að gera slíkt pegar um ímyndaða vöru er að ræða. Flest bendir pó til pess að kynningarstarfið geti haft veigamikil áhrif á árangur útvíkkunar, sér í lagi pegar farið er í útvíkkun í lítið eða ótengda vöruflokka. Skortur er á rannsóknum á sviðinu par sem tekið er tillit til kynningarstarfsins og mikilvægt er að fræðasamfélagið bregðist við peim skorti svo heildstæðari mynd verði til og dýpri pekking á áhrifapáttum á árangur við útvíkkun vörumerkja.

\section{Um höfundana}

Auður Hermannsdóttir er aðjúnkt við viðskiptafræðideild Háskóla Íslands. Netfang: audurhermannsdottir@hi.is. Pálína Mjöll Pálsdóttir er meistaranemi við viðskiptafræðideild Háskóla Îslands.

\section{Heimildir}

Aaker, D. (1990). „Brand extensions: The good, the bad, and the ugly.“ Sloan Management Review, 31, 47-56.

Aaker, D.A. og Keller, K.L. (1990). „Consumer evaluations of brand extensions.“ Journal of Marketing, 54, 27-41. http://dx.doi.org/10.2307/1252171

Arikan, E.S. (2010). „Potential determinants of brand extension success: Direct and indirect effects.“ The Journal of American Academy of Business, Cambridge 16, 151-157. 
Balachander, S. og Ghose, S. (2003). „Reciprocal spillover effects: A strategic benefit of brand extensions." Journal of Marketing, 67, 4-13. http://dx.doi.org/10.1509/jmkg.67.1.4.18594

Baltar, F. og Brunet, I. (2012). „Social research 2.0: Virtual snowball sampling method using Facebook." Internet Research, 22, 57-74. http://dx.doi.org/10.1108/10662241211199960

Barone, M.J., Miniard, P.W. og Romeo, J.B. (2000). „The influence of positive mood on brand extension evaluations." Journal of Consumer Research, 26, 386-400. http://dx.doi.org/10.1086/209570

Batra, R., Lehmann, D.R. og Singh, D. (1993). „The brand personality component of brand goodwill: Some antecedents and consequences. "I D.A. Aaker og A. Biel (ritstjórar), Brand equity and advertising: Advertising's role in building strong brands (bls. 83-97). Hillsdale, N.J.: Erlbaum.

Bottomley, P.A. og Holden, S.J.S. (2001). „Do we really know how consumers evaluate brand extensions? Empirical generalizations based on secondary analysis of eight studies." Journal of Marketing Research, 38, 494-500. http://dx.doi.org/10.1509/jmkr.38.4.494.18901

Boush, D.M. og Loken, B. (1991). „A process-tracing study of brand extension evaluation.“ Journal of Marketing Research, 28, 16-28. http://dx.doi.org/10.2307/3172723

Bowlby, J. (1979). The making and breaking of affectional bonds. London: Tavistock.

Breivik, E. og Thorbjørnsen, H. (2008). „Consumer brand relationships: An investigation of two alternative models." Journal of the Academy of Marketing Science, 36, 443-472. http://dx.doi.org/10.1007/s11747-008-0115-Z

Bridges, S., Keller, K.L. og Sood, S. (2000). „Communication strategies for brand extensions: Enhancing perceived fit by establishing explanatory links." Journal of Advertising, 29, 1-11. http://dx.doi.org/10.1080/00913367.2000.10673620

Broniarczyk, S.M. og Alba, J.W. (1994). „The importance of the brand in brand extension.“ Journal of Marketing Research, 31, 214-228. http://dx.doi.org/10.2307/3152195

CNN Money (2006, 23. maí). „Nike shoes catch up with iPod mania.“"Vefslóð: money.cnn.com/2006/05/23/technology/personaltech/nike_apple

Collins-Dodd, C. og Louviere, J.J. (1999). „Brand equity and retailer acceptance of brand extensions.“ Journal of Retailing and Consumer Services, 6, 1-13. http://dx.doi.org/10.1016/S0969-6989(97)00039-8

Curasi, C.F. og Kennedy, K.N. (2002). „From prisoners to apostles: a typology of repeat buyers and loyal customers in service businesses." Journal of Services Marketing, 16, 322-341. http://dx.doi.org/10.1108/08876040210433220

Doyle, P. (2001). „Shareholder-value-based brand strategies.“ Journal of Brand Management, 9, 20-30. http://dx.doi.org/10.1057/palgrave.bm.2540049

Fedorikhin, A., Park, C.W. og Thomson, M. (2008). „Beyond fit and attitude: The effect of emotional attachment on consumer responses to brand extension." Journal of Consumer Psychology, 18, 281-291. http://dx.doi.org/10.1016/j.jcps.2008.09.006

Fournier, S. (1998). „Consumers and their brands: Developing relationship theory in consumer research." Journal of Consumer Research, 24, 343-353. http://dx.doi.org/10.1086/209515

Goodson, S. (2011, 27. nóvember). „Is brand loyalty the core to Apple’s success?“ Forbes. Vefslóð: www.forbes.com/sites/marketshare/2011/11/27/is-brand-loyalty-the-core-to-apples-success-2

Gouville, J.T. (2007). „Eager sellers and stony buyers: Understanding the psychology of new-product adoption." Harvard Business Review, 84, 98-106. 
Hunter, L. (2012). „Challenging the reported disadvantages of e-questionnaires and addressing methodological issues of online data collection." Nurse Researcher, 20, 11-20.

Interbrand (2012). Best global brands 2012. Vefslóð: interbrand.com/Libraries/Branding_Studies/Best_Global_Brands_2012.sflb.ashx

Interbrand (2013). Best global brands 2013. Vefslóð: www.interbrand.com/Libraries/Branding_Studies/Best_Global_Brands_2013.sflb.ashx

Iversen, N.M. og Hem, L.E. (2011). „Reciprocal transfer effects for brand extensions of global or local origin: evidence from Norway." International Marketing Review, 28, 365-411. http://dx.doi.org/10.1108/02651331111149949

Jung, K. og Tey, L. (2010). „Searching for boundary conditions for successful brand extensions.“ Journal of Product \& Brand Management, 19, 276-285. http://dx.doi.org/10.1108/10610421011059595

Keller, K.L. og Lehmann, D.R. (2006). „Brands and branding: Research findings and future priorities.“ Marketing Science, 25, 740-759. http://dx.doi.org/10.1287/mksc.1050.0153

Klink, R.R. og Smith, D.C. (2001). „Threats to the external validity of brand extension research.“ Journal of Marketing Research, 38, 326-335. http://dx.doi.org/10.1509/jmkr.38.3.326.18864

Lane, V. og Jacobson, R. (1995). „Stock market reactions to brand extension announcements: The effects of brand attitude and familiarity." Journal of Marketing, 59, 63-77. http://dx.doi.org/10.2307/1252015

Liu, X., Hu, M.Y. og Grimm, P.E. (2010). „Affect transfer in brand extensions: The role of expectancy and relevancy." Journal of Product \& Brand Management, 19, 317-326.

http://dx.doi.org/10.1108/10610421011068559

Magnoni, F. og Roux, E. (2012). „The impact of step-down line extension on consumer-brand relationships: A risky strategy for luxury brands." Journal of Brand Management, 19, 595-608. http://dx.doi.org/10.1057/bm.2012.8

Maoz, E. og Tybout, A.M. (2002). „The moderating role of involvement and differentiation in the evaluation of brand extensions." Journal of Consumer Psychology, 12, 119-131. http://dx.doi.org/10.1207/S15327663JCP1202_05

Martínez, E. og Pina, J.M. (2003). „The negative impact of brand extension on parent brand image.“ Journal of Product and Brand Management, 12, 432-448. http://dx.doi.org/10.1108/10610420310506001

Monga, A.B. og John, D.R. (2010). „What makes brands elastic? The influence of brand concept and styles of thinking on brand extension evaluation." Journal of Marketing, 74, 80-92. http://dx.doi.org/10.1509/jmkg.74.3.80

Morgan-Thomas, A. og Veloutsou, C. (2013). „Beyond technology acceptance: Brand relationships and online brand experience." Journal of Business Research, 66, 21-27. http://dx.doi.org/10.1016/j.jbusres.2011.07.019

Neale, L., Baazeem, T. og Bougoure, U. (2009). „The effect of brand extension on parent-brand relationship quality." Ritgerð kynnt á ráðstefnu Australian and New Zealand Marketing Academy. Vefslóð: eprints.qut.edu.au/29718

Nkwocha, I., Bao, Y., Johnson, W.C. og Brotspies, H.V. (2005). „Product fit and consumer attitude toward brand extensions: The moderating role of product involvement." Journal of Marketing Theory and Practice, 13, 49-61. Vefslóð: www.jstor.org/stable/40470227

Nunnally, J.C. (1978). Psychometric theory. 2. útgáfa. New York: McGraw-Hill. 
Oakley, J.L., Duhachek, A., Balachander, S. og Sriram, S. (2008). „Order of entry and the moderating role of comparison brands in brand extension evaluation. "Journal of Consumer Research, 34, 706-712. http://dx.doi.org/10.1086/521905

O'Loughlin, D., Szmigin, I. og Turnbull, P. (2004). „From relationships to experiences in retail financial services. “International Journal of Bank Marketing, 22, 522-540. http://dx.doi.org/10.1108/02652320410567935

Papista, E. og Dimitriadis, S. (2012). „Exploring consumer-brand relationship quality and identification: Qualitative evidence from cosmetics brands." Qualitative Market Research, 15, 33-56. http://dx.doi.org/10.1108/13522751211191982

Park, C.W., Jaworski, B.J. og MacInnis, D.J. (1986). „Strategic brand concept-image management.“ Journal of Marketing, 50, 135-145. http://dx.doi.org/10.2307/1251291

Park, J., Kim, K. og Kim, J. (2002). „Acceptance of brand extensions: Interactive influences of product category similarity, typicality of claimed benefits, and brand relationship quality." Advances in Consumer Research, 29, 190-198.

Reast, J.D. (2005). „Brand trust and brand extension acceptance: The relationship.“ Journal of Product \& Brand Management, 14, 4-13. http://dx.doi.org/10.1108/10610420510583707

Romeo, J.B. (1991). „The effect of negative information on the evaluations of brand extensions and the family brand." Advances in Consumer Research, 18, 399-406.

Schouten, J.W. og McAlexander, J.H. (1995). „Subcultures of consumption: An ethnography of the new bikers." Journal of Consumer Research, 22, 43-61. http://dx.doi.org/10.1086/209434

Smit, E., Bronner, F. og Tolboom, M. (2007). „Brand relationship quality and its value for personal contact." Journal of Business Research, 60, 627-633. http://dx.doi.org/10.1016/j.jbusres.2006.06.012

Smith, D.C. og Park, W. (1992). „The effects of brand extensions on market share and advertising efficiency." Journal of Marketing Research, 29, 296-313. http://dx.doi.org/10.2307/3172741

Spiggle, S., Nguyen, H.T. og Caravella, M. (2012). „More than fit: Brand extension authenticity.“ Journal of Marketing Research, 49, 967-983. http://dx.doi.org/10.1509/jmr.11.0015

Tauber, E.M. (1988). Brand leverage: Strategy for growth in a cost-control world. Journal of Advertising Research, 28, 26-30.

Thorbjørnsen, H., Supphellen, M., Nysveen, H. og Pedersen, P.E. (2002). „Building brand relationships online: A comparison of two interactive applications. "Journal of Interactive Marketing, 16, 17-34. http://dx.doi.org/10.1002/dir.10034

Veloutsou, C. (2007). „Identifying the dimensions of the product-brand and consumer relationship.“ Journal of Marketing Management, 23, 7-26. http://dx.doi.org/10.1362/026725707X177892

Völckner, F. og Sattler, H. (2006). „Drivers of brand extension success.“ Journal of Marketing, 70, 18-34. http://dx.doi.org/10.1509/jmkg.70.2.18

Wiskus, D. (2013, 24. janúar). „The secret of Apple's design success: The humane interface.“ Macworld. Vefslóð: www.macworld.com/article/2025988/the-secret-of-apples-design-successthe-humane-interface.html

Xie, D. og Heung, V.C.S. (2012). „The effects of brand relationship quality on responses to service failure of hotel consumers." International Journal of Hospitality Management, 31, 735-744. http://dx.doi.org/10.1016/j.ijhm.2011.09.010 